\title{
Local and Global Poverty: Insights Using a Rights-based Approach
}

\section{Ankita Deka}

\begin{abstract}
Social workers have proposed various conceptual models to explain the relationship between structural oppressions and poverty. These models are grounded in critical social work and each provides an understanding of how systemic issues impact the sustenance and reinforcement of poverty. With rapid economic globalization and further social and economic exclusion faced by people, poverty has become even more deep and complex. This paper argues for the adoption of a rights-based framework in social work to address issues of endemic structural poverty. Grounded on the principle of the inalienability of basic human rights, the rights-based approach changes the discourse on poverty by creating accountability, equality, transparency and participation from welfare states and civil society. The paper also provides a critique against traditional human rights perspectives in poverty alleviation. The paper provides a context in which the rights-based approach could be pursued in global as well as local contexts.
\end{abstract}

Keywords: Poverty, rights-based approach, social exclusion, human rights

In the last few decades, social work professionals have used various conceptual and theoretical approaches in understanding and addressing global and local poverty as it relates to social inequities and structural injustice (Krumer-Nevo, 2008; Weiss, 2003). Many of these approaches have their roots in critical perspectives which allow practitioners to develop anti-oppressive practices that challenge the historical and contemporary subordination of marginalized groups (Morley, 2008). Given the tenuous relationship of neoliberalism and capitalism with the role of the welfare state, it has become fairly apparent that social services for the most marginalized have become an unnecessary victim. In the context of this volatile body politic, social work educators, practitioners and researchers have to facilitate strategies for change that can counter the marginalizing effects of poverty both in the local and global sphere. The purpose of this paper is to propose a conceptual framework based on the rights-based approach that will be able to integrate critical social pedagogies even as it advocates for the restoration of the inalienable rights of individuals and groups who are most vulnerable in society. This approach has been used in countries of the global south with marginalized populations; however this approach is somewhat new to the anti-poverty interventions in social work in the United States. The paper also argues against the more conservative rights-based approaches applied in social work that uses the notion of rights and obligations as a dualistic, reciprocal function.

\section{RIGHTS-BASED APPROACH}

A rights-based approach to address poverty in social work would imply the focus and attention on the attainment of a human life with respect and dignity for those that face much vulnerability in society as an outcome of being poor. In the development literature where this approach has been widely used, the approach is multi-thronged with

Ankita Deka, MSW, Ph.D., is an Assistant Professor in the Department of Social Work at Augsburg College in Minneapolis, MN.

Copyright (C) 2012 Advances in Social Work Vol. 13 No. 2 (Summer 2012), 471-483 
implications for legal, socioeconomic and political rights (InsightShare, 2011). Historically, the rights-based approach was used by development organizations because the earlier models of delivery of goods and services by the welfare state to address systemic problems of poverty and marginalization was deemed unsuccessful on various fronts (Offenheiser \& Holcombe, 2003). Research has also indicated that over reliance on the market forces to "lift all boats" when it comes to poverty alleviation has not been particularly successful either. Studies suggest that in most countries the chasm between the rich and the poor is ever widening, and many groups are unable to make it out of the poverty traps (Nambissan, 2010). Therefore, given that the shrinking welfare state is much less accountable to deliver for the poor and the marginalized, and where marketfriendly policies are creating wealth concentration in the hands of few, poverty alleviation is best approached from the rights-based perspective. Essentially, the rightsbased approach re-conceptualizes our understanding about poverty by elaborating a fundamental difference in our understanding of the 'poor as helpless victims'. It explains poverty as an outcome of social exclusion and marginalization and envisions that the poor are stakeholders who are capable of shaping their destiny. Therefore the poor are no longer perceived as vulnerable citizens who merely need public goods and services to alleviate their suffering, but they are stakeholders who challenge the fundamentals of how resources and goods are allocated and distributed in society.

The rights-based approaches have been used and understood in many different ways in the development literature with some of the fundamental principles of this perspective including; participation, accountability, equality and non-discrimination, transparency, and empowerment (Gready, 2008). Rights-based approaches have their root in the fundamentals of human rights perspectives that address issues of inalienable political, economic, legal and social rights for those that are disenfranchised in the society. However, it is widely acknowledged that the human rights perspective in general has been unable to address poverty and pro-poor policy related issues for a very long time (Gready, 2008). For example, poverty related issues were not central to the human rights discussion early on mainly because of the over emphasis on civil and political rights for most of the $20^{\text {th }}$ century (Lauren, 1998). Even in countries of the global north humans rights perspectives frequently sidelined the emphasis on economic, social and cultural rights (Frediani, 2010). The main reason that was argued against inclusion of these rights was that they were not enforceable by law. Therefore, the centrality of human rights approaches were often based on the workings of the legal systems, implying the precedence of rights that could ultimately be enforced through legislation.

In the late $20^{\text {th }}$ century and early $21^{\text {st }}$ century, rights-based approaches have been able to broaden their scope of addressing issues of social disenfranchisement. Gready (2008) says that in the post globalization era, various stakeholders such as non-governmental organizations, civil society organizations were able to argue for a more comprehensive set of rights. These rights focused on the "indivisibility of civil-political and economicsocial rights, process and outcomes, engagement on multiple levels from the local to the global, top-down and bottom-up approaches, public and private spheres, individual and collective rights, service delivery or emergency responses, and structural change” (Gready, 2008, p. 736). These complex set of rights have provided opportunities for 
various stakeholders to engage in interventions that helps establish a more concrete approach to poverty, which can challenge systematic structural barriers that impact the lives of those living in poverty.

Rights-based approaches are based on a shift from a technical understanding of rights to a politically motivated understanding which is premised on three key components: that individuals have rights, the state or government is obliged to safeguard those rights, and people need to participate for the attainment of those rights (Eyben, 2005). Amartya Sen's critical work on the relationship between poverty and human rights has also influenced the development of the rights-based approaches. Sen (1999) puts a new emphasis on the relationship between entitlements, opportunities, freedoms and poverty (Eyben, 2005). He suggests that 'functioning and capabilities' which also refer to achievements and access to resources and goods in society are crucial components in explaining well being of individuals (Frediani, 2010). The capabilities approach of Amartya Sen informs the rights-based approach in several ways. First it allows for the non-utilitarian understanding of poverty as a mere outcome of material deprivation. Second it can provide the framework for expansion of freedoms for those who are deprived, and those other actors such as the state needs to play a pro-active role to facilitate the enhancement of freedoms (Frediani, 2010). The rights-based approach is a viable strategy for addressing poverty as it supports the notion of universality that all human beings share a common humanity that needs to be realized irrespective of their national origin, gender, ability, religion, racial ethnic identity or culture. However, this tenet of universality does not strip away the fact that all rights are rooted in the context of being; therefore rights are essentially local in nature. Ife and Fiske (2006) have further developed the idea of localization of universal rights by stating that although most universal rights have been widely critiqued for their over dependence on western philosophical tradition, while the universality of rights does not necessarily imply a homogenizing effect. They argue that the moral humanity associated with the concept of rights does not mean sameness where every individual needs to fit a certain normative ascription of the attainment of rights (Ife \& Fiske, 2006).

The rights-based approach is consistent with social values and ethics, the social work profession is committed to the idea of creating equity and justice for individuals and groups that are at the margins of society. The inclusion of rights decenters the mainstream debate on poverty where poverty is seen as an outcome of individual pathologies rather than as an outcome of exclusionary social structures. The rights-based approach also allows us to explore that poverty also co-exists with other forms of social oppression such as racism, sexism, ableism, and ageism (Davis \& Wainwright, 2005). The fight against poverty therefore is clearly a political strife that looks into historical and contemporary forces that perpetuate, reinforce and sustain social inequities. In that sense the rights-based approach is premised on the belief that it is a counter to top-down policies and programs that have attempted to alleviate poverty without taking into context the lived experiences of those living in poverty. This paper argues that a rights-based approach has to be understood as a critical social intervention against poverty that uses a bottom up strategy with stakeholders. This approach allows for room to explore the 
intersectionalities of structural oppressions and how they create advantages for few and lack of privileges for others.

\section{EXPLORATION OF POVERTY DISCOURSE IN SOCIAL WORK}

The professionalization of social work has simultaneously led to more focus of the discipline on systems and processes of social exclusion (Davis \& Wainwright, 2005). Since its inception the late $19^{\text {th }}$ century social workers have been interested in issues related to the poor (Krumer-Nevo, Weiss-Gal, \& Monnickendam, 2009). The professional code of ethics also clearly outlines the commitment of the profession in addressing poverty (National Association for Social Workers, 2000). At the international level social workers are committed to addressing issues related to poverty and social justice. Much of this commitment is seen as a response to the growing number of poor within countries, and also the country to country differences when it comes to poverty rates (Krumer-Nevo, et al., 2009). The market friendly policies and structural adjustment programs initiated in the last two decades in countries of the global south have also created significant hardships for the poor within countries (Nambissan, 2010). Conceptualizing and measuring poverty is also considerably difficult as different institutions and entities have varying interpretations of poverty. Most definitions of poverty are expert driven, and have very little perspective from the poor themselves (Serr, 2004). Poverty is usually defined in terms of absolute and relative terms; absolute poverty refers to lack of sufficient income for basic needs and relative poverty refers to poverty in relation to income levels of others in the society (Serr, 2004).

The global poverty rate, or percentage of people living under less than $\$ 1.25$ a day has declined, absolute poverty rates have remained steady (Woolcock, 2008). The regional differences both within and outside the countries however have a huge influence in the interpretation of this data. While China and India have experienced the decline of poverty in both relative and absolute terms, very little has changed in Latin America, and Africa continues to have high numbers of people experiencing absolute poverty (Woolcock, 2008). In the United States, in the post recession period from 2007-2008, about 47 million people lived below the government defined poverty line (Abramsky, 2012). Within these figures, there are huge disparities by race as well; while a quarter of Blacks and Latinos live under the government defined poverty estimates, about $12 \%$ of Asian-Americans and less than $10 \%$ of Whites live under the poverty line (Abramsky, 2012). Poverty continues to pose a serious threat to populations living both in the United States and other parts of the world.

Around the world social work professionals continue to interface poverty through their clients, since significant number of social work clients even when they have other overt problems also experience poverty (Healy, 2008). Social work literature on poverty related issues often takes a critical view of individualized interventions and models of practice that are incapable of explaining the structural issues and their causal relation with poverty (Krumer-Nevo, et al., 2009).

Poverty interventions in social work in the United States is not altogether new, the $19^{\text {th }}$ century Charity Organizing Societies (COS) and Settlement House (CH) movements 
are some of the earliest known organized efforts to address poverty within the profession. The two approaches differed in outlook on poverty, with the COS focusing on the pathology of individuals experiencing poverty and how aid from the state could create long term dependency (Weiss, 2003). The SHM focused on understanding how structural issues created challenges for an individual to achieve their full potential including their material and financial well-being. Modern casework largely evolved from the COS orientation that put emphasis on orienting an individual to the environment by improving their psychological health (Weiss, 2003). On the other hand SHM significantly influenced the development of advocacy and activist strategies that critically examines the role of the state and other agencies in the financial deprivation and marginalization of certain groups (Abramovitz, 1998; Weiss, 2003).

Contemporary social work practice on poverty alleviation is clearly influenced by the historical ideological orientations. Neo-conservative values and assumptions within social work challenge individuals facing poverty to take personal accountability of their condition; they advocate that the welfare state should restrict its role of service delivery and should allow the market to provide opportunities for all (Weiss, 2003). Radical social workers have critiqued the over-emphasis on the psycho-pathology of individuals living in poverty and have instead advocated for state level interventions through policies and programs to address systemic and structural causes of poverty. Social work practice is heavily influenced by values, assumptions and ideologies; therefore it is not surprising that the literature is ripe with varying approaches and orientations toward issues related to poverty. The long standing tension between individual versus structural causes of poverty is often blurred by the normative assumptions of social workers.

International literature on poverty has also enlisted the idea of poverty as a process of social exclusion, whereby individuals are denied access to full participation in civil society, which restricts their ability to seek and benefit from social, economic and cultural goods (Davis \& Wainwright, 2005). The concept of social exclusion takes into account the various factors such as age, race, gender and ability, it also throws light on the compounding effect of exclusions and how it creates economic and social vulnerability (Becker, 2002). Poverty as social exclusion paradigm was popularized in Britain because of growing social inequities that could not merely be attributed to income disparity, hence a more holistic approach of understanding poverty as the loss of dynamic access to individual, social, cultural and political goods was later developed (Barry \& Hallett, 1998). Poverty research in recent years has also shifted its vision to include the lived experiences of those living in poverty in the centre stage of poverty discourse. This perspective alters the traditional understanding of viewing the poor as lacking any legitimate understanding and input on the conditions that impact their lives (KrumerNevo, 2008).

\section{ECONOMIC GLOBALIZATION}

In recent years discourses related to the impact of economic globalization and its impact on the vulnerable populations, particularly the poor have received much attention. Neo-liberal policies and structural adjustment programs introduced in countries of the global south have had profound influence on national policies, particularly on pro-poor 
policies (Triegaardt, 2008). Economic globalization has allowed for the capital mobility and the proliferation of capitalist growth, while the poorest people on the planet have been adversely affected by the fallouts of globalization such as low paying jobs, loss of social safety nets, and loss of sources of livelihoods (Dominelli, 2010). As a phenomenon, globalization has been described in various ways such as the integration of global economies, social and cultural transactions, transference of western individualistic values around the world and the likes. Economic globalization has resulted in the nation states cutting back on subsidies and assistance to the poor. In South Africa, for example, the poor have mobilized to demand access to basic services such as housing, sanitation and water (Ballard, Habib, \& Valodia, 2006). Globalization has transformed the modernist idea of a welfare state as a proactive agent in the development and enforcement of social welfare policies (Ahmadi, 2003). Globalization has created a shift in roles, where international relief and aid agencies are taking over the role of nation states in addressing problems of endemic poverty (Jordan, 2008). Social workers in many countries of the global south are highly critical of anti-poverty programs fostered in conjunction with economic liberalization. Their main contention is that globalization intensifies the economic and social disparities between groups, particularly between those who hold privilege in society and those that have been historically sidelined. Globalization does not operate in value neutral or gender neutral ways; therefore in countries such as Africa where women are subjugated to the very bottom ranks in society, the economic benefits of globalization of women are usually never accessible to women (Sawpaul, 2001).

Social work research and practice has put significant efforts in developing and implementing various strategies for poverty alleviation, the approaches mentioned are some of the most recent innovations in the literature, while the discussion is not comprehensive it provides some insights into the poverty and social work literature internationally.

\section{RIGHTS-BASED APPROACH AND POVERTY ALLEVIATION STRATEGY}

Community based movements around the world have become very active in response to growing levels of income and wealth disparity, environmental degradation, lack of sustainable growth (Gooden, 2008; Pyles \& Lewis, 2007). These movements have often taken the issues of the poor to the center stage of the political landscape. Much of this community work is geared toward transformation of systems and structures that allow inequities to thrive in society (Mizrahi, 2001). Social work practice particularly in recent years has come under a lot of fire for losing the firebrand activism and radical thoughts that was the hallmark of the profession in its early years. The increasing tilt of the profession toward micro interventions following the lead of evidence based medicine is a historic reinforcement of the COS methodologies. Although, clinical social work will always be a key aspect of the profession's identity, it is unfortunate that social workers are abandoning the pursuit of the ideals of structural equity and justice (Jewell, Collins, Gargotto, \& Dishon, 2009). Resource constraints, growing backlash from conservative legislators are some of the key reasons that keep social workers disengaged from public 
discourse on disenfranchisement of our key constituencies (Jewell, et al., 2009). Although the construct of social justice for all is adequately addressed in the NASW code of ethics, there is a functional treatment meted out to the concepts vis-à-vis practice. Many social workers are not engaged in massive social transformation efforts through advocacy and mobilization, therefore they are not presented with opportunities to apply their expertise in achieving social justice (Abramovitz, 1998).

With growing populations of people living in poverty around the world it is imperative on social workers to reactivate our synergies of working to transform institutions and structures that allow inequities to thrive. The rights-based approach is rooted in critical pedagogy that challenges essentialist ideas of poverty as a phenomenon of those who are lazy, irresponsible and therefore unworthy of social support (Sidel, 2000). The rights-based approach challenges the hopelessness that is embodied in this rhetoric, which fails to account for how historical and contemporary policies and structures allow for intergenerational poverty to thrive. Rights-based approaches provides a tool for social workers to identify and name the social inequalities that perpetuate social injustice and inequities (Offenheiser \& Holcombe, 2003). A rights-based approach in social work could pay particular attention to issues of vulnerability and disempowerment in specific local contexts. All social identity groups face discrete challenges depending on how and where they interface dominance and subjugation. Therefore, it is important to understand that although the paper argues for a universal appeal toward integrating rights-based approaches in social work, the fundamental marker of this approach is that the interventions are only contextual and local in nature. Therefore, a rights-based strategy to fight rural poverty in India could differ significantly from the strategies of combating urban poverty in the United States. The argument here is that as a philosophical, moral, value orientation rights-based approach provides a radical context for social workers to understand and challenge the status quo on the plight of the poor.

In order to outline the basic framework of a rights-based intervention on poverty, I adopted Kapur \& Duvvury's (2006) assumptions about the approach . Although, Kapur \& Duvvary's work focuses mainly on the development agenda, the framework outlined below pays specific attention to poverty intervention. The framework provides an opportunity for the dualistic reciprocal function of rights and responsibilities outlined in the human rights perspective to be revisited. The critical piece about this framework is that it lends legitimacy to the rights of an individual, which are otherwise often dubbed as entitlements by the welfare state. In order for an individual to live a life of human dignity (human rights principle), the individual is entitled to access and exercise those rights. It also puts onus on the welfare state as well as civil society organizations to provide access to the rights. The reciprocal dualism envisaged through this framework is distinctly different from the human rights perspective in general, which does not acknowledge the complexity in which rights and duties are often manifested. Some key areas to explore are as follows:

- Exploring and understanding the locale of vulnerability, who are the perpetrators, existing power imbalances, and recognizing power hierarchies.

- Building accountability and transparency in right holders and duty bearers. 
- Strengthening local capacities through training and support (critical community mobilization) that will allow right holders exercise their right vis-à-vis their vulnerability, and duty holders to seek and meet obligations.

- Facilitating stakeholder participation, particularly those whose lives are adversely affected by poverty.

- Empowering stakeholders to critically appraise how violation of their social, political, economic and cultural rights has contributed to their state of poverty. Consciousness rising is a key outcome of this approach.

- Developing competence among stakeholders to articulate and advocate effectively about other intersecting forms of oppression that compound their state of poverty.

This framework is a versatile tool for social workers to engage in anti-poverty interventions, when they are fully cognizant that various social identity groups such as women face varying levels of oppression that compounds their poverty. Rights-based framework of understanding gendered poverty for example in countries of the global south can for example focus on how women often lack decision-making power in the formal and informal sphere, they have little or no access to markets, and they continue to share the highest burden of poverty (Ruwanpura, 2004). Understanding this critical nexus of material deprivation with structural oppressions such as race, gender, class, sexual orientation, employment and income can provide significant breakthroughs in poverty alleviation strategies by social workers. A feminist redefinition of this approach has often highlighted few key components: focus on social versus individual nature of rights; rights are often pursued in relational and communal contexts; rights should reinforce the need for redistribution of resources; and right bearers need to be identified in regards to their multiple social identities (Kapur \& Duvvury, 2006). For example in the work with girls education in India, the approach facilitated a shift in cultural patterns where traditionally girl's education was opposed simply because it was established cultural norm (Kapur \& Duvvury, 2006). This approach facilitated windows of opportunity for the community to take control on their collective destinies (Kapur \& Duvvury, 2006). Additionally, in a study by Jewell et al. (2009), the authors described an anti-poverty program that used a human rights perspective for critical education and appropriate intervention on poverty. Several aspects of this intervention had close orientations with the rights-based framework. The Women In Transition (WIT) group made up of former welfare recipients used their leverage to educate and develop support against poverty, developed a strong toolbox of skills for members such as programs on strength and resilience to combat poverty in their lives (Jewell, et al., 2009).

The rights-based approach provides an apt context for social workers interested in anti-poverty work. Although the orientation of the framework is philosophical in nature given its value orientation in the inalienable rights of individuals, the framework can provide concrete community mobilization strategies. In that sense unlike other approaches that are merely of esoteric significance, the rights-based a approach can be used as a tool for consciousness raising and social change as it relates to poverty. The 
framework also provides a great platform to understand the complex nature of American poverty with its intersectionalities in race, class, gender, sexual orientation, ability and age. The specific analyses on power structures in society can help pin-point the locales of many forms of systematic oppressions and their impact on poverty. The key aspect of the approach is that it is a process geared toward social change, in that sense it is not an end in itself (Kapur \& Duvvury, 2006). As with any other approach, particular attention needs to be given on the planning strategy, community organization, consciousness raising and social action, empowering communities by building capacities, networking with other stakeholder groups and organizations, organizational growth and development, and finally an ongoing evaluation and monitoring of strategies (Kapur \& Duvvury, 2006). The key distinction is that most stakeholders will remain stakeholders in the process, this entire design and execution of strategies toward poverty alleviation must be driven by stakeholder participation. In sum, the rights-based approach is a strategy for anti-poverty work and it fits naturally with social work interventions and our professional values.

\section{LIMITATIONS OF THE RIGHTS-BASED APPROACH}

Although the rights-based approach presents several opportunities for social workers to understand and address issues of structural injustice and inequity as it relates to poverty, it is not without its challenges. Jewell et al. (2009) state that there are specific challenges in implementing a human rights perspective in anti-poverty interventions. The three challenges they identified were: identity politics, legitimization from other organizations, and organizational barriers. While the rights-based perspective differs in its value orientation from human rights in that it focuses much less on the dualist reciprocal function of rights and duties of citizens, nevertheless there are overlaps in the approaches. Hence, it is legitimate to expect some of the same concerns impacting the rights-based initiatives. Jewell et al. (2009) point out that given the historic nature of marginalization and identity formulations, it is hard to find common ground and language to address poverty concerns among many groups. On one hand the identity formulations provide visibility to subordinated groups, on the other hand it is harder for the groups to see how different issues can be connected to multiple identities (Jewell, et al., 2009). Therefore, it is a practical challenge to incorporate the intersection of the poverty phenomenon with the intersections of identities in a framework. The other challenge in incorporating a rights-based approach in anti-poverty work is that institutions are generally classist in nature, and because this perspective confronts the basis of this institutional classism, it is possible that institutions may alienate themselves from poverty movements (Jewell et al; 2009). As with any movement or organization fighting against structural injustice, rights-based advocates are likely to face resource constraints particularly given the nature of the work.

Although, the rights-based approach differs significantly from a human rights perspective, there is some confusion among professionals about the distinction. Since the human rights perspective focuses more on a universal set of rights that are presumed to be enforceable by law, there is some unease among certain constituents about its commitment in addressing systemic causes that causes the violation of rights in the first place. Also the human right perspective tends to rely heavily on civil and political rights 
and pays much less attention to economic, cultural and social rights. Rights-based approach advocates have to be mindful about creating a framework whereby there are able to explain the similarities and difference between the approaches. Finally, rightsbased approaches like many other advocacy and social change strategies requires a certain kind of political will from various stakeholders including social workers for it to be successful. Given the complexity of the nature of this intervention in unearthing power and oppressions, and mobilizing stakeholders for social action, there are considerable challenges in steering the work. Although, the limitations need to be carefully examined, it is imperative that social workers do not get dissuaded from this approach of poverty alleviation. The challenges can be outweighed by the significant opportunities that the approach can present to many vulnerable social work constituents.

\section{IMPLICATIONS FOR SOCIAL WORK PRACTICE}

The rights-based approach will provide social workers engaged in anti-poverty intervention work a perspective of interrogating systemic structures and processes that perpetuate poverty. Using this type of strategy, social workers can create new foray and linkages between traditional community organizing and direct social action. The rightsbased approach is an effective strategy that has both universal and local appeal. In other words, although the philosophical arguments in favor of the approach may might initially appear somewhat universal in nature, nevertheless in reality the approach is grounded on diverse local contexts. Rights-based approaches although widely popular in countries of the global south such as India, can be relevant in understanding poverty in western contexts. Furthermore, the rights-based approach offers a critical social perspective even for clinical social workers by creating a compelling argument in favor of exploring the larger context in which social work clients seek services. The rights-based approach provides a critical framework to social work professionals to advocate for a just and equitable society where systems of oppressions based on social exclusions can be dismantled. The character of social work needs to be redefined by our active engagement in such public discourse and social workers should be in the frontline of this work (MacKinnon, 2009).

\section{References}

Abramovitz, M. (1998). Social work and social reform: An arena of struggle. Social Work, 43(6), 512-526.

Abramsky, S. (2012, May 14). The other America 2012, The Nation, pp. 11-18.

Ahmadi, N. (2003). Globalisation of consciousness and new challenges for international social work. International Journal of Social Welfare, 12(1), 14-23.

Ballard, R., Habib, A., \& Valodia, I. (2006). Making sense of post-apartheid South Africa's voices of protest. In R. Ballard, A. Habib \& I. Valodia (Eds.), Voices of protest: Social movements in post-apartheid South Africa (1st ed., pp. 397-418). Scottsville, South Africa: University of KwaZulu-Natal Press. 
Barry, M., \& Hallett, C. (Eds.). (1998). Social exclusion and social work: Issues of theory, policy and practice (1st ed.). Dorset, UK: Russell House Publishing.

Becker, S. (2002). "Security for those who cannot'’: Labour's neglected welfare principle. Poverty, 112, 13-17s.

Davis, A., \& Wainwright, S. (2005). Combaing poverty and social exclusion: Implication for social work education. Social Work Education, 24, 259-273.

Dominelli, L. (2010). Globalization, contemporary challenges and social work practice. International Social Work, 53(5), 599-612. doi: 10.1177/0020872810371201

Eyben, R. (2005). Linking power and poverty reduction. In R. Alsop (Ed.), Power, rights, and poverty: Concepts and connections (15-28). Washington, DC: The World Bank and DFID.

Frediani, A. A. (2010). Sen's capability approach as a framework to practice of development. Development in Practice, 20(2), 173-187.

Gooden, A. (2008). Community organizing by African Caribbean people in Toronto, Ontario. Journal of Black Studies, 38(3), 413-426. doi: 10.1177/0021934707309134

Gready, P. (2008). Rights-based approaches to development: What is value-added? Development in Practice, 18(6), 735-747.

Healy, L. M. (2008). Exploring the history of social work as a human rights profession. International Social Work, 51(6), 735-748.

Ife, J., \& Fiske, L. (2006). Human rights and community work: Complementary theories and practices. International Social Work, 49(3), 297-+. doi:

$10.1177 / 0020872806063403$

InsightShare. (2011). A rights-based approach to participatory video: toolkit. Retrieved from http://insightshare.org/sites/default/files/A\%20Rights-

Based\%20Approach\%20to\%20Participatory\%20Video\%20\%20toolkit\%20\%28CHAPTER\%202\%29.pdf

Jewell, J. R., Collins, K. V., Gargotto, L., \& Dishon, A. J. (2009). Building the unsetting force: Social workers and the struggle for human rights. Journal of Community Practice, 17(3), 309-322.

Jordan, B. (2008). Social work and world poverty. International Social Work, 51(4), 440+. doi: $10.1177 / 0020872808090238$

Kapur, A., \& Duvvury, N. (2006). A rights-based approach to realizing the economic and social rights of poor and marginalized women. Washington, DC: International Center for Research on Women.

Krumer-Nevo, M. (2008). From noise to voice: How social work can benefit from the knowledge of people living in poverty. International Social Work, 51(4), 556-+. doi: $10.1177 / 0020872808090248$ 
Krumer-Nevo, M., Weiss-Gal, I., \& Monnickendam, M. (2009). Poverty-aware social work practice: A conceptual framework for social work education. Journal of Social Work Education, 45(2), 225-243.

Lauren, P. G. (1998). The evolution of international human rights: Visions seen. Philadelphia: University of Pennsylvania Press.

MacKinnon, S. T. (2009). Social work intellectuals in twenty-first century: Critical social theory, critical social work and public engagement. Social Work Education, 28(5), 512-527.

Mizrahi, T. (2001). The status of community organizing in 2001: Community practice context, complexities, contradictions, and contributions. Research on Social Work Practice, 11(2), 176-189.

Morley, C. (2008). Teaching critical practice: resisting structural domination through critical reflection. Social Work Education, 27(4), 407-421.

Nambissan, G. B. (2010). The global economic crisis, poverty and education: a perspective from India. Journal of Education Policy, 25(6), 729-737.

National Association for Social Workers. (2000). International policy on human rights. Policy statement excerpted from Social work speaks (5th. ed.). Washington, DC: Author. Retrieved from http://www.socialworkers.org/pressroom/events/911/humanrights.asp

Offenheiser, R. C., \& Holcombe, S. H. (2003). Challenges and opportunities in implementing a rights-based approach to development: An Oxfam America perspective. Nonprofit and Voluntary Sector Quarterly, 32(2), 268-301. doi: 10.1177/0899764003251739

Pyles, L., \& Lewis, J. S. (2007). Women of the storm: Advocacy and organizing in postKatrina New Orleans. Affilia-Journal of Women and Social Work, 22(4), 385-389. doi: Doi 10.1177/0886109907306305

Ruwanpura, K. N. (2004). Quality of women's employment: A focus on the South. Geneva: International Institute of Labour Studies.

Sawpaul, V. (2001). Economic globalizafion and social policy reform: Social work curricula in the South African context. Maatskaplike Werk/Social Work, 37(4), 309323.

Sen, A. (1999). Development as freedom. New York: Random House.

Serr, K. (2004). Voices from the bottom. Australian Social Work, 57(2), 137-149.

Sidel, R. (2000). The enemy within: The demonization of poor women. Journal of Sociology and Social Welfare, 27(1), 73-84.

Triegaardt, J. D. (2008). Globalization: What impact and opportunities for the poor and unemployed in South Africa? International Social Work, 51(4), 480-+. doi: $10.1177 / 0020872808090241$ 
Weiss, I. (2003). Social work students and social change: On the link between views on poverty, social work goals and policy practice. International Journal of Social Welfare, 12(2), 132-141.

Woolcock, M. ( 2008). Global poverty and Inequality: A brief retrospective and prospective analysis. The Political Quarterly, 79(S1), 183-196.

\section{Author note:}

Address correspondence to: Ankita Deka, Department of Social Work, Augsburg College, 2211 Riverside Ave, CB 51, Minneapolis, MN 55113. Email:

deka@augsburg.edu 